\title{
Potensi Penambahan Probiotik (Lactobacillus pentosus K50) untuk Meningkatkan Kualitas Pakan Ikan Air Tawar
}

\author{
Helena Daten ${ }^{1)}$, Tri Ardyati ${ }^{1{ }^{*}}$ \\ 1)Jurusan Biologi, Fakultas Matematika dan Ilmu Pengetahuan Alam, Universitas Brawijaya \\ ${ }^{*}$ Alamat korespondensi: tri_ardyati@yahoo.com
}

\begin{abstract}
ABSTRAK
Pakan merupakan sumber nutrisi bagi ikan yang dapat diproses dengan penambahan probiotik. Probiotik merupakan mikroba yang berperan untuk meningkatkan kesehatan inang dan kualitas pakan. Penelitian ini bertujuan untuk mengetahui viabilitas bakteri asam laktat (BAL), jumlah bakteri Salmonella dan coliform, kapang, serta kandungan nutrisi pakan yang difermentasi. Perlakuan fermentasi terdiri dari tanpa penambahan BAL (kontrol), penambahan BAL Sp. 1, probiotik (Lactobacillus pentosus K50), dan bakteri konsorsium (Lactobacillus pentosus K50 dan BAL Sp. 1). Jumlah BAL, Salmonella dan coliform serta kapang dideteksi dengan metode Total Plate Count. Kandungan protein diuji menggunakan metode Kjedahl, karbohidrat dengan metode total carbohydrate by difference, dan lemak, abu, serta air dengan metode gravimetri. Viabilitas BAL pada perlakuan penambahan BAL Sp.1 mengalami penurunan dari hari ke-0 sampai 20, sedangkan perlakuan dengan penambahan Lactobacillus pentosus $\mathrm{K50}$ dan konsorsium meningkat dari hari ke- 0 sampai 20 berturut-turut $12,6 \times 10^{8} \mathrm{cfu} / \mathrm{g}$ menjadi $17,4 \times 10^{8} \mathrm{cfu} / \mathrm{g}$ dan $11,2 \times 10^{8} \mathrm{cfu} / \mathrm{g}$ menjadi $14,9 \times 10^{8} \mathrm{cfu} / \mathrm{g}$. Bakteri Salmonella tidak tumbuh dalam pakan kontrol dan fermentasi. Jumlah bakteri coliform dan kapang dalam pakan terfermentasi dengan perlakuan probiotik dan bakteri konsorsium mengalami penurunan hari ke-5 sampai 20. Jumlah kapang pada perlakuan dengan penambahan BAL Sp. 1 mengalami fluktuasi disebabkan meningkatnya kadar air selama fermentasi. Kandungan protein relatif stabil, sedangkan kandungan lemak, karbohidrat, dan abu mengalami penurunan selama fermentasi. Penambahan probiotik dalam pakan dapat menghambat pertumbuhan bakteri coliform dan kapang, serta menjaga stabilitas nutrisi pakan.
\end{abstract}

Kata kunci: fermentasi, pakan ikan, probiotik, protein, viabilitas BAL

\section{Potency of Probiotic (Lactobacillus pentosus K50) Application to Improve Feed Quality of Freshwater Fish}

\author{
Helena Daten ${ }^{1)}$, Tri Ardyati ${ }^{1{ }^{*}}$ \\ ${ }^{1)}$ Biology Department, Faculty of Mathematics and Natural Sciences, Brawijaya University \\ "Email: tri_ardyati@yahoo.com
}

\begin{abstract}
Feed is the nutrition sources for fish which could be processed by applying probiotic. Probiotic is microbe applied to improve the health of host and feed quality. The objective of this study was to observe the viability of lactic acid bacteria (LAB), number of Salmonella, coliform and mold also nutritional contents of fermented feed. Fermentation treatment consisted of feed without application of LAB (control), application of LAB Sp. 1, probiotic (Lactobacillus pentosus K50) and consortium bacteria (Lactobacillus pentosus $\mathrm{K50}$ and LAB Sp. 1). The density of LAB, Salmonella, coliform, and mold was counted using Total Plate Count method. Protein content was assayed using Kjedahl method; carbohydrate content was assayed using total carbohydrate by difference method; and fat, ash also water content were assayed using gravimetric method. Viability of LAB in the feed treated with LAB Sp. 1 decreased from 0 to 20 days, while application of Lactobacillus pentosus $\mathrm{K50}$ and consortium bacteria increased the viability 0 to 20 days from $12.6 \times 10^{8} \mathrm{cfu} / \mathrm{g}$ to $17.4 \times 10^{8} \mathrm{cfu} / \mathrm{g}$ and $11.2 \times 10^{8} \mathrm{cfu} / \mathrm{g}$ to $1.9 \times 10^{8} \mathrm{cfu} / \mathrm{g}$, respectively. Salmonella bacteria was not detected in all fermented feeds. The number of coliform and mold in fermented feeds treated of probiotic as well as consortium bacteria decreased from 5 to 20 days. The number of mold in feeds treated with LAB Sp. 1 was fluctuated due to the increasing of water content during fermentation. However, protein content was relatively stable. While fat, carbohydrate, and ash content decreased during fermentation. Application of probiotic inhibited coliform and mold growth, also maintained the stability of feed nutrition.
\end{abstract}

Keywords: fermentation, fish feeds, probiotic, protein, viability of LAB

Jurnal Biotropika | Vol. 6 No. 2 | 2018 


\section{PENDAHULUAN}

Berkembangnya perikanan air tawar perlu didukung oleh tersedianya pakan. Kondisi ini kurang menguntungkan bagi peternak ikan skala kecil karena biaya untuk membeli pakan sangat besar yang berimbas pada rendahnya keuntungan yang diterima. Situasi ini diperparah dengan lokasi peternak ikan yang jauh dari pabrik pakan sehingga dibutuhkan banyak biaya [1].

Probiotik menurut WHO [2]) adalah mikroba hidup dalam jumlah yang cukup dapat memberikan manfaat kesehatan inangnya. Jumlah yang cukup dimaksud oleh WHO adalah $10^{6}-10^{8} \mathrm{cfu} / \mathrm{g}$ dan dapat berkembang menjadi $10^{12} \mathrm{cfu} / \mathrm{g}$ di dalam kolon. Mekanisme kerja probiotik dengan menekan populasi mikroba patogen melalui kompetisi memproduksi senyawa-senyawa antimikroba atau kompetisi nutrisi dan merubah metabolisme mikrobial dengan meningkatkan atau menurunkan aktivitas enzim pengurai. Selain itu, probiotik juga menstimulasi imunitas melalui peningkatan kadar antibodi organisme akuatik atau aktivitas makrofag. Salah satu bakteri yang berpotensi sebagai probiotik adalah Lactobacillus pentosus K50. Bakteri ini dapat menghambat pertumbuhan mikroba patogen seperti $E$. coli dengan luas zona bening $73,25 \mathrm{~mm}^{2}$, Salmonella thypimurium dan Helicobacter pylori dengan luas zona bening berturut-turut $160,91 \mathrm{~mm}^{2}$ dan $353,48 \mathrm{~mm}^{2}$. Bakteri ini hidup pada $\mathrm{pH} 5$ dan 7,5 serta konsentrasi garam empedu 0-0,3 $\%$ [3]. Kualitas pakan ikan yang baik tidak mengandung Salmonella, coliform maksimum 3 koloni/g, kapang maksimum 50 koloni $/ \mathrm{g}$, dan aflatoksin maksimum 50 koloni/g [4]. Oleh karena itu, tujuan dari penelitian adalah mengetahui viabilitas bakteri asam laktat (BAL), jumlah bakteri Salmonella dan coliform, kapang, serta kandungan nutrisi pakan yang difermentasi.

\section{METODE PENELITIAN}

Komposisi dan Proses Pembuatan Pakan Ikan. Komposisi pakan ikan adalah tepung ikan $55 \mathrm{~kg}$, tepung tapioka $5 \mathrm{~kg}$, dedak $17,5 \mathrm{~kg}$, pollard $5 \mathrm{~kg}$, CGF $12,5 \mathrm{~kg}$, vitamin 2 $\mathrm{kg}$, dan feed addictive $3 \mathrm{~kg}$ (molase $2 \mathrm{~kg}+$ minyak ikan $1 \mathrm{~kg}$ ) serta ditambahkan $0,5 \mathrm{~kg}$ minyak sayur. Bahan-bahan yang berbentuk cair dicampurkan dengan tepung tapioka menggunakan vertical mixer. Setelah itu, semua bahan dicampur menggunakan horizontal mixer selama 30 menit.

Isolasi BAL dan Uji Sinergisme. Isolasi BAL dari pakan ikan menggunakan media de Man Rogosa Sharpe (MRS) agar yang mengandung $\mathrm{CaCO}_{3} 1 \%$ dan diinkubasi pada suhu $37{ }^{\circ} \mathrm{C}$ selama $48 \mathrm{jam}$. Isolat murni hasil isolasi dilakukan cat Gram dan uji katalase. Uji sinergisme dilakukan dengan digores silang antar isolat $\mathrm{BAL}$ dengan L. pentosus K50 dan diinkubasi pada suhu $37{ }^{\circ} \mathrm{C}$ selama 48 jam. Sinergisme terjadi apabila kedua isolat dapat tumbuh tanpa menghasilkan zona hambat.

Fermentasi Pakan. Jumlah sel BAL yang ditambahkan dalam fermentasi adalah $10^{9} \mathrm{cfu} / \mathrm{g}$. Kontrol adalah pakan yang tidak ditambahkan BAL Sp. 1, probiotik, dan bakteri konsorsium. Perlakuan fermentasi terdiri dari penambahan BAL Sp. 1, Lactobacillus pentosus K50, dan bakteri konsorsium (BAL Sp. 1 dan Lactobacillus pentosus K50) $10 \%$ dalam $200 \mathrm{~g}$ masing-masing pakan. Uji viabilitas BAL, deteksi bakteri Salmonella, coliform, kapang dan kandungan nutrisi serta $\mathrm{pH}$ diukur pada hari ke-0, 5, 10, 15, dan 20 .

Uji Viabilitas BAL dan Kandungan Mikroba Pencermar. Uji viabilitas BAL dan jumlah mikroba pencemar dalam pakan menggunakan metode Total Plate Count. Uji viabilitas $\mathrm{BAL}$ menggunakan media MRS agar yang mengandung $\mathrm{CaCO}_{3} 1 \%$ dan diinkubasi pada suhu $37{ }^{\circ} \mathrm{C}$ selama 48 jam. Isolasi kapang menggunakan media Potato Dextrose Agar (PDA) yang mengandung $50 \mathrm{ppm}$ streptomycin dan diinkubasi pada suhu $30{ }^{\circ} \mathrm{C}$ selama 48 jam, sedangkan bakteri Salmonella dan coliform dalam media xylose lysine deoxycholate (XLD) agar dan diinkubasi pada suhu $37{ }^{\circ} \mathrm{C}$ selama 48 jam.

Penentuan Kadar Protein dengan Metode Kjeldahl, kadar Lemak, Air, Abu, dan Karbohidrat. Prinsip kerja uji protein adalah destruksi, destilasi dan titrasi [5]. Kandungan lemak dihitung secara gravimetri [6]; kandungan air dihitung secara gravimetri [7]; kandungan abu dihitung secara gravimetri [8]; dan analisis karbohidrat menggunakan metode total carbohydrate by difference [9].

Analisis Data. Analisis data dengan one way ANOVA menggunakan SPSS 16.0. Analisis 
ini bertujuan untuk mengetahui perbedaan viabilitas BAL, bakteri Salmonella, coliform, kapang, dan kandungan nutrisi dalam pakan selama fermentasi pada berbagai perlakuan. Masing-masing perlakuan diuji statistik dengan tingkat kepercayan $95 \%(\alpha=0,05)$.

\section{HASIL DAN PEMBAHASAN}

Bakteri asam laktat yang diperoleh dari pakan ikan sebanyak tujuh isolat. Ketujuh isolat tersebut adalah isolat Sp. 1, Sp. 2, Sp. 3, Sp. 4, Sp. 5, Sp. 6, dan Sp. 7. Semua isolat mempunyai bentuk bulat, Gram positif dan ukuran sel $\pm 1 \mu \mathrm{m}$, serta katalase negatif. Isolat yang menunjukkan tidak ada antagonisme dengan $L$. pentosus $\mathrm{K} 50$ hanya isolat BAL Sp. 1

Viabilitas Bakteri Asam Laktat dalam Pakan Ikan. Jumlah sel BAL Sp. 1 yang ditambahkan dalam fermentasi pakan sebanyak $1,01 \times 10^{9} \mathrm{cfu} / \mathrm{g}$. Peningkatan jumlah BAL dalam pakan kontrol tidak drastis sehingga perubahan $\mathrm{pH}$ juga relatif stabil pada hari ke-0 sampai 20. Penurunan jumlah BAL setelah ditambahkan BAL Sp. 1 terjadi pada hari ke10 sampai 20 (Gambar 1).

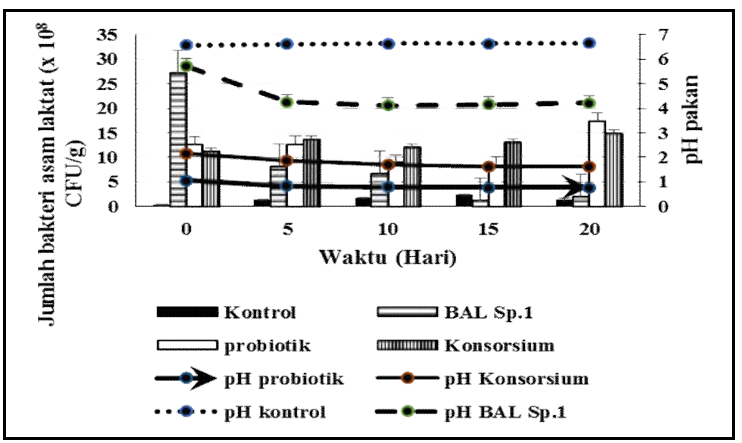

Gambar 1. Viabilitas BAL dan perubahan $\mathrm{pH}$ selama fermentasi pakan

Jumlah sel $L$. pentosus K50 yang ditambahkan dalam fermentasi sebanyak 1,089 x $10^{9} \mathrm{cfu} / \mathrm{g}$. Jumlah BAL mengalami penurunan pada hari ke-10 sampai 15 berturutturut sebanyak $8,9 \times 10^{8} \mathrm{cfu} / \mathrm{g}$ menjadi $8,4 \times$ $10^{8} \mathrm{cfu} / \mathrm{g}$ (Gambar 1). Penurunan jumlah BAL diikuti dengan penurunan $\mathrm{pH}$ 4,01 menjadi 3,92. Bakteri L. pentosus K50 dapat hidup pada $\mathrm{pH}$ 4-7 [3], sedangkan BAL umumnya dapat tumbuh pada kisaran $\mathrm{pH}$ 3-7. Selain itu, penurunan jumlah BAL disebabkan akumulasi asam laktat yang semakin banyak mengakibatkan tidak terjadi transport unsur hara ke dalam sel [10]. Peningkatan BAL terjadi kembali pada fermentasi hari ke-20. Hal ini terjadi karena pada hari ke-20 kandungan air meningkat dan protein relatif stabil (Gambar 4) sehingga digunakan sebagai nutirisi untuk tumbuh.

Jumlah sel bakteri konsorsium masingmasing yang ditambahkan dalam fermentasi sebanyak $1,085 \times 10^{9} \mathrm{cfu} / \mathrm{g}$ (BAL Sp. 1) dan 1,012 x $10^{9} \mathrm{cfu} / \mathrm{g}$ (L. pentosus K50). Viabilitas BAL setelah ditambahkan bakteri konsorsium mengalami penurunan jumlah selama fermentasi hari ke-5 sampai ke-15. Peningkatan jumlah BAL terjadi pada hari ke-20 sebanyak $14,9 \times 10^{8} \mathrm{cfu} / \mathrm{g}$. Meningkatnya jumlah BAL selama fermentasi disebabkan aktivitas proteolitik BAL dalam memecah protein menjadi asam amino dan peptida yang digunakan sebagai sumber nitrogen untuk pertumbuhan dan perbanyakan sel [10].

\section{Jumlah Bakteri Salmonella dan Coliform} dalam Pakan Ikan. Bakteri yang dideteksi dalam pakan sebagai kontrol kualitas adalah Salmonella dan coliform. Bakteri Salmonella tidak tumbuh dalam pakan kontrol dan pakan fermentasi. Jumlah bakteri coliform dalam pakan kontrol hari ke-0 menurun sampai hari ke-20 (Gambar 2).

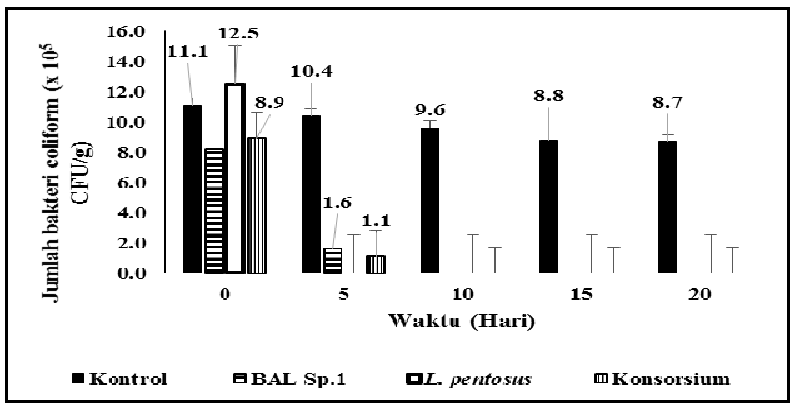

Gambar 2. Jumlah bakteri coliform selama fermentasi pakan

Jumlah bakteri coliform menurun selama fermentasi dengan penambahan BAL Sp. 1 yaitu pada hari ke-0 sebanyak $8,2 \times 10^{5} \mathrm{cfu} / \mathrm{g}$ dan pada hari ke-5 sebanyak $1,6 \times 10^{5} \mathrm{cfu} / \mathrm{g}$. penambahan BAL Sp. 1 dengan jumlah coliform berkorelasi lemah karena jumlah BAL selama fermentasi mengalami penurunan yang drastis (Gambar 2). Jumlah coliform yang tumbuh dalam pakan fermentasi dengan penambahan $L$. pentosus K50 pada hari ke-0 sebanyak $12,5 \times 10^{5} \mathrm{cfu} / \mathrm{g}$ dan tidak tumbuh sampai hari ke- 20. Kandungan bakteri coliform setelah ditambahkan bakteri konsorsium pada hari ke-0 sebanyak $9 \times 10^{7} \mathrm{cfu} / \mathrm{g}$ dan masih terdapat coliform yang tumbuh pada hari ke-5 karena wadah dan proses pengadukan saat fermentasi kurang steril sehingga terkontaminasi 
dengan mikroba patogen. Penurunan jumlah coliform terjadi karena penumpukan asam laktat menyebabkan kebocoran nutrien dan menghambat kerja enzim intraseluler sehingga menghambat proses metabolisme sel [10].

Jumlah Kapang dalam Pakan Ikan. Jumlah kapang dalam pakan kontrol meningkat dari hari ke-0 sampai hari ke-20. Jumlah kapang dalam pakan yang difermentasi dengan penambahan BAL Sp. 1 mengalami fluktuasi (Gambar 3). Kapang dengan kadar air berkorelasi kuat karena semakin tinggi kadar air maka jumlah kapang semakin banyak. Jumlah kapang yang meningkat disebabkan komposisi pakan yang berasal dari biji-bijian yang mengandung air, karbohidrat, protein, mineral, lemak, dan vitamin yang merupakan nutrisi pendukung tumbuhnya kapang.

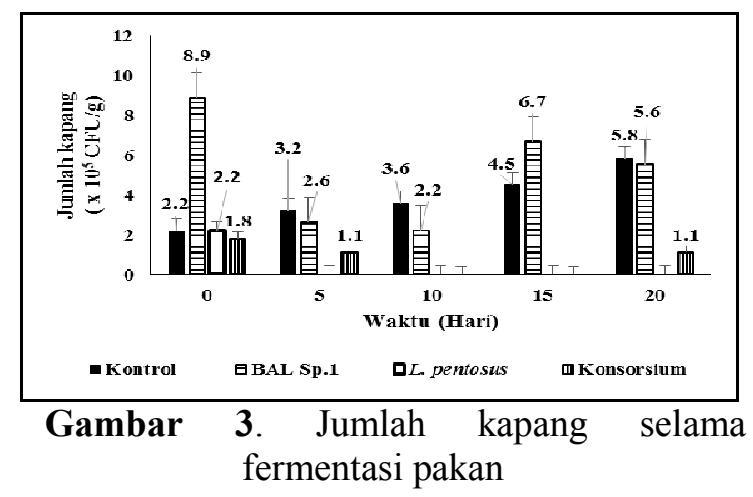

Jumlah kapang dalam pakan fermentasi yang ditambahkan $L$. pentosus K50 tidak tumbuh selama fermentasi hari ke-5 sampai 20. Hal ini terjadi karena hasil metabolisme berupa asam laktat bekerja menghambat mikroba patogen dengan melepaskan proton dari grup karboksilik yang mengakibatkan penurunan $\mathrm{pH}$ lingkungan, untuk menyeimbangkan $\mathrm{pH}$ internal maka sel mengeluarkan banyak energi menyebabkan sel kehilangan viabilitas. Penambahan $L$. pentosus K50 berkorelasi negatif dengan jumlah kapang yaitu semakin banyak L. pentosus K50 yang ditambahkan maka semakin sedikit jumlah kapang.

Jumlah kapang dalam pakan yang difermentasi dengan penambahan bakteri konsorsium mengalami penurunan jumlah pada hari ke-5, tetapi tumbuh pada hari ke-20 (Gambar 3), karena BAL bekerja tidak maksimal sehingga asam laktat yang dihasilkan tidak melawan pertumbuhan kapang. Menurut Damayanti dkk [11] dalam kondisi ekstrim asam laktat tidak bersifat sebagai penghambat, tetapi sebagai faktor pendukung pertumbuhan kapang dan dapat bersifat sebagai kofaktor dalam pembentukan aflatoksin. Mekanisme ini didasarkan teori bahwa pada suatu substrat yang mempunyai konsentrasi asam laktat yang berlebih maka sel berusaha untuk mengoksidasi kembali asam laktat tersebut menjadi piruvat untuk mendapatkan energi dan mekanisme proteksi terhadap lingkungan yang ekstrim.

Kandungan Nutrisi dalam Pakan Ikan. Kandungan nutrisi pakan terdiri dari protein, lemak, air, abu, dan karbohidrat. Kandungan karbohidrat pakan kontrol dan pakan yang difermentasi dengan penambahan BAL Sp. 1, $L$. pentosus $\mathrm{K} 50$, dan bakteri konsorsium mengalami penurunan pada hari ke-0 sampai hari ke-20. Kadar air setelah fermentasi mengalami peningkatan menjadi lebih dari $12 \%$. Air yang dihasilkan merupakan air bebas yang akan menguap saat pengeringan menggunakan cahaya matahari atau oven.

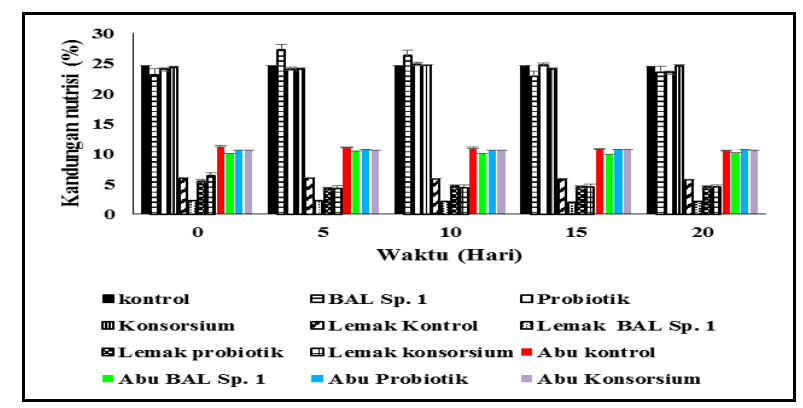

Gambar 4. Kandungan protein, lemak, dan abu dalam pakan

Kandungan protein, lemak, dan abu dalam pakan kontrol dan penambahan BAL Sp. 1 mengalami penurunan pada hari ke-0 sampai 20 . Kandungan protein dalam pakan yang difermentasi L. pentosus K50 dan bakteri konsorsium relatif stabil pada hari ke-0 sampai 20 berturut-turut sebanyak 24,71\% menjadi 24,05\% dan 24,4 \% menjadi 24,66\% (Gambar 4). Penurunannya disebabkan aktivitas proteolitik BAL dalam memecah protein menjadi asam amino dan peptida yang digunakan sebagai sumber nitrogen untuk pertumbuhannya [12]. Berdasarkan kandungan protein dalam pakan yang difermentasi dengan BAL Sp. 1, L. pentosus K50, dan bakteri konsorsium maka protein tersebut cocok untuk jenis ikan Patin usia pembesaran karena protein yang dibutuhkan ikan patin usia pembesaran adalah $25 \%$ [13]. Penurunan jumlah lemak karena BAL memiliki aktivitas lipolitik 
sekunder yang dapat memecah lemak menjadi senyawa kimia yang lebih sederhana. Penurunan jumlah abu terjadi karena mikroba menggunakan mineral untuk mempertahankan hidupnya meskipun dalam jumlah yang sedikit. Berdasarkan ketiga perlakuan tersebut dapat disimpulkan bahwa fermentasi dengan penambahan $L$. pentosus K50 dapat meningkatkan kualitas pakan ikan karena tidak menurunkan jumlah nutrisi pakan dan dapat menghambat pertumbuhan mikroba pencemar.

\section{KESIMPULAN}

Kesimpulan yang didapatkan dari penelitian adalah viabilitas BAL dalam tiga perlakuan fermentasi pakan pada hari ke-0 sampai 20 relatif stabil sebanyak $10^{8} \mathrm{cfu} / \mathrm{g}$. Bakteri Salmonella tidak tumbuh dalam pakan kontrol dan fermentasi. Pakan dengan penambahan BAL Sp. 1 dapat menghambat pertumbuhan coliform tetapi tidak menghambat pertumbuhan kapang. Bakteri $L$. pentosus K50 dan konsorsium dapat menurunkan jumlah coliform dan kapang. Kandungan protein relatif stabil pada pakan yang difermentasi dengan penambahan BAL, probiotik dan bakteri konsorsium. Kandungan lemak, abu, dan karbohidrat mengalami penurunan tidak drastis, sedangkan air semakin meningkat selama proses fermentasi.

\section{UCAPAN TERIMA KASIH}

Ucapan terima kasih kepada Balai Besar Perikanan Budidaya Air Tawar, Sukabumi, Jawa Barat yang sudah mensuplai pakan ikan dan Ibu Dra. Nanik Dwi Rahayu selaku laboran Mikrobiologi, Fakultas Matematika dan Ilmu Pengetahuan Alam, Universitas Brawijaya.

\section{DAFTAR PUSTAKA}

[1] Sarry, I. R. 2013. Produksi pakan buatan, Kementrian Pendidikan dan Kebudayaan, Jakarta.

[2] WHO. 2001. Health and nutritional properties of probiotics in food including powder milk with live lactic acid bacteria, FAO Food and Nutrition Paper. 2-18.

[3] Karim, A. 2016. Uji potensi bakteri asam laktat dari susu Kuda Sumbawa (Equus ferus caballus) sebagai probiotik.
Jurusan Biologi, Fakultas Matematika dan Ilmu Pengetahuan Alam, Universitas Brawijaya. Malang, Skripsi.

[4] SNI. 2009a. Pakan buatan untuk ikan gurami (Osphronemus goramy, Lac.), SNI 65.120-7548.

[5] Magomya, A.M., D. Kubmarawa., J. A. Ndahi \& G.G. Yebpella. 2014. Determination of Plant Protein Via The Kjeldahl Method and Amino Acid Analysis: A Comparative Study. International Journal of Scieentific \& Technology Research. 3 (4): 2277-8616.

[6] SNI. 2006a. Cara uji kimia penentuan kadar lemak total pada produk perikanan, SNI 012354.3.

[7] SNI. 2006b. Cara uji kimia penentuan kadar air pada produk perikanan, SNI 01-2354.2.

[8] LU-BBPBATS. 2015. Metode pengujian kadar abu, $L U$-BBPBATS-III,5.4.1.23.

[9] SNI. 1992. Cara uji makanan dan minuman, SNI 01-2891.

[10] Al-rawi, A. A. M. M \& A. T. Al-mola. 2009. Antimicrobial activity of lactic acid bacteria isolated from minced beef meat against some patogenic bacteria. Iraqi Journal of Veterinary Science. 23 (1): 115117.

[11] Damayanti, E., A. E. Suryani., A. Sofyan, M. F. Karimy \& H. Julendra. 2015. Seleksi bakteri asam laktat dengan aktivitas anti jamur yang diisolasi dari silase dan saluran cerna ternak. Journal of Agritechnology. 35 (2): 164-169.

[12] Nisa, A. K \& A. K. Wardani. 2016. Pengaruh lama pengasapan dan lama fermentasi terhadap sosis fermentasi ikan Lele (Clarias gariepinus). Jurnal Pangan dan Agroindustri. 4 (1): 367-376.

[13] SNI. 2009b. Pakan buatan untuk ikan Patin (Pangasius sp.), SNI 65.120-7548. 
